\title{
RESPONSABILIZAÇÃO NA LEI ANTICORRUPÇÃO: NatureZa E Amplitude SubJetiva
}

\author{
ACCOUNTABILITY IN THE ANTI-CORRUPTION LAW: \\ Nature ANd SubJective RANGe
}

\section{RESPONSABILIZACIÓN EN LA LEY ANTICORRUPCIÓN: Naturaleza y Amplitud SubJetiva}

\author{
Cristiana Maria Fortini Pinto e Silva* \\ Lucas Dutra Dadalto**
}

1 A corrupção e suas possíveis raízes no Brasil. 2 A Lei Anticorrupção. 3 Responsabilização na Lei n ${ }^{\circ}$ 12.846/13: natureza e alcance subjetivo. 4 Sujeitos ativos e passivos. 5 FCPA, UK Bribery act e Lei Anticorrupção: análise comparativa da amplitude subjetiva desses diplomas. 6 Conclusão. Referências.

\section{RESUMO}

O presente artigo busca abordar a questão da responsabilização na Lei $\mathrm{n}^{0} 12.846 / 2013$, também chamada de Lei Anticorrupção, a partir da definição de sua natureza jurídica e da delimitação de sua amplitude subjetiva. Antes disso, far-se-á rápida digressão para explanar o tema da Corrupção a partir de suas raízes históricas, demonstrando sua presença, desde os primórdios da colonização brasileira até os dias atuais. Destaca-se, assim, o liame temporal que acabou por desembocar na edição da Lei Anticorrupção como uma forma de completar o sistema legal pátrio de defesa da moralidade. No núcleo do artigo, questiona-se se a amplitude da referida lei também abarcaria a responsabilização das pessoas físicas responsáveis pelos atos lesivos definidos neste diploma ou se esta lei se restringiria apenas à responsabi-

* Graduação em Direito pela Universidade Federal de Minas Gerais (1995). Doutorado em Direito pela Universidade Federal de Minas Gerais (2003). Pós Doutorado/Estágio Senior (bolsa Capes) na George Washington University (2015). Professora da graduação, mestrado e doutorado (corpo permanente) na Faculdade de Direito da UFMG. Professora do mestrado (corpo permanente) da Faculdade de Direito Milton Campos. Belo Horizonte - MG - BR. E-mail: <cristianafortini@carvalhopereirarossi.adv.br> http://orcid.org/0000-0003-1384-0183

** Analista Judiciário no TRF da 2a região. Mestrando (ex-bolsista CAPES) em Direito Administrativo na Universidade Federal de Minas Gerais (UFMG). Bacharel em Direito pela Universidade Federal Fluminense (UFF), com período cursado na Faculdade de Direito da Universidade de Granada, Espanha. Belo Horizonte - MG - BR. E-mail: <lucasdadalto@id.uff.br>.http://orcid.org/0000-0002-3831-7105 
lização das pessoas jurídicas. Procura-se delimitar de forma mais objetiva os sujeitos ativos e passivos abarcados pela Lei Anticorrupção e como as sanções previstas se amoldam às especificidades de cada caso. Tudo isso visa a favorecer sua aplicação racional, sempre em homenagem ao princípio da segurança jurídica.

Palavras-chave: Lei anticorrupção. Corrupção. Sujeito ativo. Sujeito passivo. Responsabilidade objetiva.

\begin{abstract}
This article seeks to address the issue of the subjective scope defined in Law 12.846/2013, also known as the Anti-Corruption Law, from the definition of its legal nature and the delimitation of its subjective range. Before that, we will make a quick digression to present the theme of Corruption from its historical roots, by demonstrating its presence since the beginnings of the Brazilian colonization until the present day. We highlight, therefore, the temporal bond that ended up leading to the edition of the Anti-Corruption Law as a way to complete the legal system of defense of morality. In the core of the article, we questioned whether the scope of this law would also include the liability of the individuals responsible for the harmful acts defined in this law or if this law would be restricted to the liability of legal entities. From this point of view, we aim to delimit more objectively the active and passive subjects covered by the Anti-Corruption Law and how the sanctions provided in the new legislation conform to the specificities of each case. All this aims to favor its rational and logical application in combination with the other laws that are part of the normative system to combat corruption, always in honor of the principle of legal certainty.
\end{abstract}

Keywords: Anti-Corruption Law. Corruption. Active Subject. Passive Subject. Objective Responsibility.

\title{
RESUMEN
}

El presente artículo busca abordar la cuestión de la responsabilización en la Ley $\mathrm{n}^{\mathrm{o}}$ 12.846/2013, también llamada Ley Anticorrupción, a partir de la definición de su naturaleza jurídica y de la delimitación de su amplitud subjetiva. Anteriormente, se hará una rápida digresión para colocar el tema de la Corrupción a partir de sus raíces históricas, demostrando su presencia desde el principio de la colonización brasileña hasta los días actuales. Se destaca, así, el enlace temporal que acabó por llevar a la edición de la Ley Anticorrupción como una forma de completar el sistema jurídico patrio de defensa de la moralidad. En el núcleo del artículo, se cuestiona si la amplitud de dicha ley también abarcaba la responsabilización de las personas físicas responsables por los actos lesivos definidos en este diploma o si esta ley se restringiera sólo a la responsabilización de las personas jurídicas. Se busca delimitar de forma 
más objetiva a los sujetos activos y pasivos abarcados por la ley anticorrupción y cómo las sanciones previstas se amoldan a las especificidades de cada caso. Todo ello tiene por objeto favorecer su aplicación racional, siempre en homenaje al principio de seguridad jurídica.

Palabras clave: Ley Anticorrupción. Corrupción. Sujeto Activo. Sujeto Pasivo. Responsabilidad Objetiva.

\section{A CORRUPÇÃO E AS SUAS POSSÍVEIS RAÍZES NO BRASIL}

Etimologicamente, o vocábulo corrupção origina-se do latim "rumpere" (romper, separar, dividir), que acabou dando origem aos vocábulos "corrumpere" (verbo) e "corruptio" (substantivo), denotando um sentido polissêmico consistente em corromper, produzir putrefação, depravar, perverter, desmoralizar (GARCIA, 2004, p. 203; CUÉLLAR; PINHO, 2014, p. 132; BING, 2016, p. 2-3). Na mesma linha de sua raiz latina, os dicionários nacionais apontam que "corrupção" se relaciona com o ato ou efeito de corromper, devassando, subornando, estragando, destruindo, prejudicando, ou tornando algo pútrido (FERREIRA, 2008, p. 271; HOUAISS; VILLAR, 2001, p. 557).

Quando a ideia de corrupção extravasa a esfera etimológica e é incorporada como um conceito técnico-jurídico, a sua amplitude se modula, conforme as especificidades de cada ordenamento jurídico. O conceito técnico-jurídico de corrupção nunca será universal: "pode se emprestar, ao sabor da opção política do país, maior ou menor amplitude ao vocábulo, incrementando ou reduzindo a lista do que se poderia enquadrar como prática corrupta." (FORTINI; MOTTA, 2016, p. 93).

Osório (2013, p. 28) destaca o aspecto multifacetado da definição de corrupção, que envolve aspectos de ordem política, histórica, cultural, ideológica e normativa, o que acaba conferindo um traço de complexidade ao seu conceito. Conforme Coelho e Heringer (2017, p. 167): "o desafio de combate à corrupção começa pela sua conceituação."

É comum a afirmação de que a corrupção está umbilicalmente conectada à construção político-social do Brasil, desde os tempos de Colônia até a atual República Federativa. ${ }^{1}$

Nesse sentido, Bueno (2006, p. 62) afirma que o próprio sistema das capitanias hereditárias favorecia as práticas corruptivas. Segundo este autor, "abuso, corrupção e incompetência foram a regra e não exceção durante os 15 anos do regime de capitanias”. Partindo de uma visão majoritariamente sociológica, Barroso $(2017$, p. 3) destaca que existem três disfunções que marcaram a trajetória histórica do Estado Brasileiro e que podem ser relacionadas com a gênese da corrupção no Brasil: o patrimonialismo, o oficialismo e a desigualdade.

O patrimonialismo é caracterizado pela confusão entre o patrimônio público e privado, típico de Estados Absolutistas, em que não há distinção entre os bens do rei e dos súditos. Nas palavras de Holanda (1995, p. 146): "para o funcionário 'patrimonial', a própria gestão

1 Sobre a construção histórica dos traços da corrupção no Brasil, ver: (FAORO, 2012; AVRITZER; FILGUEIRAS, 2011; HABIB, 1994; SANTOS, 1989; BUENO, 2006). 
pública apresenta-se como assunto de seu interesse particular." No âmbito da Administração Pública patrimonialista os próprios interesses se confundem, não havendo divisão entre o público e o particular.

A herança patrimonialista portuguesa é constantemente destacada como uma das principais sementes da corrupção nacional, ainda que não se possa apontar uma só razão hábil a justificar a realidade brasileira. Nas palavras de Barroso (2017, p. 3, grifo nosso):

O patrimonialismo remete à nossa tradição ibérica, ao modo como se estabeleciam as relações políticas, econômicas e sociais entre o Imperador e a sociedade portuguesa, em geral, e com os colonizadores do Brasil, em particular. Não havia separação entre a Fazenda do rei e a Fazenda do reino, entre bens particulares e bens do Estado. Os deveres públicos e as obrigações privadas se sobrepunham. O rei tinha participação direta e pessoal nos tributos e nos frutos obtidos na colônia. Vem desde aí a difícil separação entre esfera pública e privada, que é a marca da formação nacional. É um traço tão forte que a Constituição brasileira precisou de um dispositivo expresso para vedar que os agentes públicos utilizassem dinheiro público para promoção pessoal. A aceitação resignada do inaceitável se manifesta na máxima "rouba, mas faz".

Silva $(2000$, p. 34) destaca que o patrimonialismo se sustenta a partir de uma estrutura formada por critérios eminentemente pessoais, com destaque para o nepotismo em sua base fundacional. Esta estrutura, obviamente, não se refere ao modelo racional-legal weberiano, ${ }^{2}$ mas a uma estrutura hermética de cargos políticos distribuídos, conforme as relações de poder pré-estabelecidas e a própria vontade pessoal do monarca (FAORO, 2012, p. 102).

O oficialismo, como decorrência direta do patrimonialismo, traduziria a relação de dependência entre particular e o aparelho estatal, materializada pela esperança de apoio e financiamento estatal aos projetos particulares: empregos públicos, subsídios, financiamentos públicos, entre outros (BARROSO, 2017 p. 4). Essa relação de dependência plasmada com o jeito receptivo e amigável do brasileiro acaba gerando a cultura paternalista tão típica do Brasil, em que os favores e os apadrinhamentos se disseminam na vida cotidiana como consequência direta da "pessoalidade" das relações entre agentes públicos e particulares.

Identificando os traços oficialistas e a cultura de apadrinhamento no período do Brasil Colônia, Habib (1994, p. 9) destaca que "eram costumeiros, também nesta fase, trocas de favores, o tráfico de influência, os conchavos, os acordos, as composições, o apadrinhamento, assim como os desvios de verbas, de que o não recolhimento de impostos era espécie."

A confusão entre o patrimônio público e privado típica do patrimonialismo se relaciona intrinsecamente com o apadrinhamento característico do paternalismo brasileiro.

Nesta perspectiva, Figueiredo (2012, p. 176) destaca a comum tradição no Período Colonial de participação das autoridades estatais em atividades comerciais, dividindo os lucros com os cofres estatais e buscando quase que sempre a obtenção de vantagens pessoais.

Assim, o "jeitinho" brasileiro surge como subproduto destas três disfunções, principalmente a partir das ideias de pessoalização das relações e da banalização da troca de favores

2 Ver: Weber (1999). 
(mesmo em situações de duvidosa legalidade). Para Barroso (2017, p. 5), o jeitinho brasileiro é tanto um aspecto cultural como uma maneira informal/alternativa (muitas vezes corrupta) de resolução de problemas nos mais diversificados ambientes e situações, traduzindo uma verdadeira cultura de flexibilização das normas sociais e/ou legais que ainda se manifesta frequentemente na sociedade brasileira.

A junção de todos estes aspectos desencadeia o aumento da "desigualdade social", já que a desproporção de privilégios e favores intensifica o abismo social entre as classes, assim como ocorria com a nobreza e a plebe nos Estados Absolutistas.

Porém, ainda que se possa detectar elementos que hoje, no Brasil, seriam considerados corruptos, a avaliação sobre o que seria corrupção e a forma de abordá-la oscilou ao longo do tempo.

Conforme destaca Carvalho (2012, p. 200 e ss.), as acusações de corrupção no Império Brasileiro, na Primeira República, dirigiam-se ao sistema, e não à pessoa do governante. Nesse viés, a população via o sistema como corrupto, mas não a autoridade que governava.

O autor destaca que a mudança semântica do conceito de corrupção ocorre apenas no fim da Era Vargas (1945), em que o foco se altera para as pessoas que governavam: os corruptos passaram a ser os indivíduos que supostamente se apropriavam do dinheiro público, in casu, os getulistas e o próprio ex-presidente (no imaginário popular). Esse sentido semântico seguiu como justificativa para o Golpe de 1964 (combate aos subversivos e corruptos) e também foi o discurso que conduziu Collor à Presidência da República ("caça aos marajás"), sendo predominante até os dias atuais.

Essa digressão histórica pode explicar o motivo de o combate à corrupção no Brasil ter sido, por tanto tempo, direcionado à pessoa física envolvida em um dos polos do ato de corrupção. Para além do Código Penal, a Lei de Improbidade Administrativa, a qual também revela a intolerância da ordem jurídica com condutas desviantes, ainda que não necessariamente passíveis de catalogação como corruptas, tem seu principal alvo os agentes públicos, ainda que alcance as pessoas jurídicas beneficiadas pelas condutas estatais.

A Lei Anticorrupção, por outro lado, tem por pretensão a responsabilização da pessoa jurídica, beneficiária exclusiva ou não do ato nela rotulada como corrupto. Partindo do pressuposto de que a represália, ainda que criminal da pessoa física, não basta para desincentivar a corrupção, a lei prevê o dever de reparar o gravame decorrente do ato ilícito, bem como sanções administrativas de caráter pecuniário direto (multa sobre faturamento bruto) ou indireto (publicação que exponha o comportamento ilícito da pessoa jurídica). ${ }^{3}$

Com a sua edição, adiciona-se importante elemento no sistema jurídico de combate à corrupção. Porém, cumpre destacar que, enquanto a Lei de Improbidade Administrativa persegue o agente público responsável pelo ato ímprobo, a Lei Anticorrupção volta-se a outro propósito, tendo a ambição de imputar responsabilidade objetiva cível e administrativa

3 A lei também prevê sanções que podem ser aplicadas no âmbito do Poder Judiciário e ainda que tenha ocorrido a responsabilização cível e administrativa. 
às pessoas jurídicas por ela alcançadas. ${ }^{4}$ São objetos distintos com amplitudes igualmente diversas: não custa lembrar que a Lei Anticorrupção surge para preencher o vácuo que existia quanto à punibilidade das pessoas jurídicas por atos lesivos à Administração Pública.

Ademais, esta divisão de leis conforme a natureza (física ou jurídica) da pessoa corrupta é peculiar ao sistema anticorrupção brasileiro, não sendo observada nos diplomas normativos que são considerados como paradigmas do combate à corrupção (FCPA e UK bribery act).

Neste sentido, a Lei Anticorrupção surge como uma tentativa de alcançar as pessoas jurídicas, seu foco, com o intuito de abarcar todos os conjuntos de agentes possivelmente envolvidos em práticas corruptas. Assim, impõe-se o dever de interpretá-la sistematicamente com a Lei de Improbidade Administrativa, afastando o risco de eventual bis in idem entre os dois diplomas:

Se presente apenas o agente público, será aplicado o regime da Lei de Improbidade, existentes os demais requisitos para sua incidência. Se o sujeito ativo for pessoa jurídica, o regime aplicável será o da Lei Anticorrupção. No caso de autoria compartilhada entre agente público e pessoa jurídica, nos moldes do que dispõe o art. $3^{\circ}$ da Lei n. 8.429/92, diante das distintas naturezas das responsabilidades previstas na Lei de Improbidade e na Lei Anticorrupção, bem como de suas repercussões na maior ou menor gravidade do processo de responsabilização, a presença do agente público atrairá a aplicação da Lei n. 8.429 / 1992, cujo regime é talhado para coibir atos de improbidade praticados por pessoas físicas contra a Administração Pública. Essa pode ser uma solução que hoje nos parece possível. (FORTINI; VIEIRA, 2018, p. 108).

Todavia, é pertinente destacar que o diferente alcance da Lei de Improbidade administrativa, que acaba possuindo um espectro mais amplo, englobando condutas que não necessariamente se enquadram como atos de corrupção: "Improbidade e corrupção relacionam-se entre si como gênero e espécie, sendo esta absorvida por aquela" (GARCIA, 2004, p. 204).

A título exemplificativo, citamos os atos de improbidade que causem lesão aos princípios da Administração Pública. Embora sejam tipificados como atos de improbidade (Art. $11^{\circ}$ da Lei 8.429/92), não são necessariamente enquadrados como atos de corrupção na forma da Lei 12.846/2013.

\section{A LEI ANTICORRUPÇÃO}

A Lei Federal n ${ }^{\circ}$ 12.846/2013 (BRASIL, 2013), usualmente chamada de Lei Anticorrupção, surge em um contexto de imensa convulsão social no Brasil, momento este representado emblematicamente pelas manifestações de junho de 2013 (CARVALHOSA, 2014b). Apesar da heterogeneidade de pautas daqueles que foram às ruas, destacava-se a insatisfação com a corrupção.

Como uma forma de resposta ao clamor popular, a Lei Federal $\mathrm{n}^{\mathrm{o}} 12.846$ foi aprovada no dia $1^{\circ}$ de agosto de 2013, fruto de um projeto apresentado pelo Poder Executivo em 2010,

4 (FORTINI, 2017). 
que, a despeito dos compromissos assumidos pelo Brasil, junto a organismos internacionais, não foi apreciado na velocidade que o tema reclamava.

A compreensão de que a Lei Anticorrupção se soma a outros diplomas normativos vocacionados à proteção da transparência e da probidade administrativa (FORTINI; VIEIRA, 2015, p. 161-162), como a Lei de Improbidade Administrativa (Lei no 8.429/1992) (BRASIL, 1992); Lei da Ficha Limpa (Lei Complementar no 135/2010) (BRASIL, 2010); Lei de Defesa da Concorrência (Lei no 12.529/2011) (BRASIL, 2011), é importante para a análise do alcance subjetivo da responsabilização civil e administrativa estabelecida por esta lei em virtude dos atos lesivos que ela cataloga como corruptos.

Costuma-se apontar que a Lei Anticorrupção brasileira se inspirou em diplomas estrangeiros como o Foreign Corrupt Practices Act (FCPA), editado na década de setenta nos Estados Unidos da América, país com destacada presença nos fóruns de discussão sobre o combate à corrupção, ainda que não posicionado de forma mais prestigiada na lista da Transparência Internacional.

Uma análise mais apurada, todavia, revela diferenças relevantes entre os diplomas, em especial diante das opções divergentes quanto às condutas a serem freadas e à natureza da responsabilidade estabelecida. Embora preocupada com o cenário das contratações públicas, o olhar da lei brasileira ultrapassa as licitações e contratos para rotular como "corruptas", a ensejar a responsabilidade civil e administrativa das pessoas jurídicas, condutas outras em nada sintonizadas com a Lei 8.666/93 (BRASIL, 1993) ou outras leis que abordam a mesma temática. ${ }^{5}$

Também se observa que o FCPA, focado apenas na corrupção a envolver agentes estrangeiros, difere da lei brasileira que não distingue o agente público envolvido. A lei estadunidense condiciona a responsabilização à comprovação do intuito corrompedor, requisito não exigido na lei brasileira. Ficando comprovada maior severidade no tratamento da matéria, a Lei 12.846/13 (BRASIL, 2013) prevê a responsabilidade objetiva e não sinaliza com hipóteses hábeis a afastá-la, indicando apenas circunstâncias atenuantes.

Em comum com o FCPA, entre outros pontos, a abordagem da corrupção que enlaça as estruturas e os agentes do Estado, sem avançar na repressão e prevenção da corrupção "privada". Nesse sentido, os diplomas brasileiros e estadunidenses se irmanam e se afastam do UK Bribery Act cuja pretensão é regular em um único diploma o tratamento legal preventivo e repressivo da corrupção, independente de sua natureza pública ou privada, ou mesmo da natureza (pessoa física ou jurídica) do sujeito ativo. ${ }^{6}$

Assim, ainda que, em certa medida, o FCPA seja importante para que diversos países, entre eles, o Brasil, se comprometessem a intensificar a luta contra a corrupção, a lei brasi-

5 O art. $5^{\circ}$ da Lei 12.846/13 (BRASIL, 2013) contém rol diversificado de comportamentos corruptos.

6 Sobre o FCPA e o UK Bribery Act, incluindo seus eventuais pontos de interseção, conferir: Lippman (2013), Rosalez, Loegering e Territt (2010), Palermo (2012), Tillipman (2014), Sporkin (1997), Koehler (2010). 
leira apresenta características peculiares que devem ser compreendidas dentro do contexto social brasileiro e do ordenamento jurídico nacional. ${ }^{?}$

Uma dessas características é a restrição da amplitude subjetiva de sua responsabilização.

\section{RESPONSABILIZAC̣ÃO NA LEI No 12.846/13: NATUREZA E ALCANCE SUBJETIVO}

Como apontam as autoras Fortini e Vieira (2015, p. 161), o objetivo central da Lei Anticorrupção é a responsabilização objetiva administrativa e civil das pessoas jurídica que pratiquem os atos lesivos definidos no mesmo diploma legal contra a Administração Pública nacional e estrangeira. Isso se depreende do próprio texto legal ${ }^{8}$, que, em seus artigos inaugurais, deixa bem claro qual será o seu ponto focal.

Para Carvalhosa (2014a, p. 33-34), a Lei 12.846/13 tem nítida natureza penal. Este autor sustenta, inclusive, que a responsabilização prevista nela lei deve seguir as regras e princípios do devido processo penal. Embebida por raciocínio análogo, a ADI no 5.261/ DF questiona a constitucionalidade do caráter objetivo da responsabilidade prevista na Lei Anticorrupção, argumentando que incidiriam princípios próprios do Direito Penal, como o da intranscendência das penas e da culpabilidade. Discordamos dos posicionamentos retro.

Sobre a natureza desta responsabilidade, o legislador teve o cuidado de dispor expressamente que a Lei Anticorrupção apenas abarcará as responsabilidades de natureza administrativa e civil. Parece que o legislador buscou evitar uma série de inconveniências que a imputação de responsabilidade penal poderia gerar.

Por estes motivos, não há qualquer óbice constitucional para que se atribua responsabilidade objetiva às pessoas jurídicas, desde que se restrinja às esferas de responsabilização civil e administrativa. Dessa forma, até por conta da expressa previsão da Lei n ${ }^{\circ}$ 12.846/2013, refuta-se a ideia de que essa lei prevê também responsabilidade penal. ${ }^{9}$

Nesse sentido, não vemos fundamento jurídico na arguição de inconstitucionalidade (ADI n $5.261 / \mathrm{DF}$ ) (BRASIL, 2015a) que contesta o caráter objetivo da responsabilidade civil e administrativa fincadas na lei, considerando os argumentos apresentados. Não há qualquer óbice constitucional para atribuição de responsabilidade objetiva às pessoas jurídicas, no que diz respeito à responsabilidade civil, considerando não apenas o fato de que

7 Sobre a comparação entre a Lei Anticorrupção e o FCPA, ver: Fortini (2015).

8 "Art. $1^{\circ}$. Esta Lei dispõe sobre a responsabilização objetiva administrativa e civil de pessoas jurídicas pela prática de atos contra a administração pública, nacional ou estrangeira. Parágrafo único. Aplica-se o disposto nesta Lei às sociedades empresárias e às sociedades simples, personificadas ou não, independentemente da forma de organização ou modelo societário adotado, bem como a quaisquer fundações, associações de entidades ou pessoas, ou sociedades estrangeiras, que tenham sede, filial ou representação no território brasileiro, constituídas de fato ou de direito, ainda que temporariamente. Art. $2^{\circ}$. As pessoas jurídicas serão responsabilizadas objetivamente, nos âmbitos administrativo e civil, pelos atos lesivos previstos nesta Lei praticados em seu interesse ou benefício, exclusivo ou não." (BRASIL, 2013, on-line).

9 Para Carvalhosa (2014a, p. 33-34), a Lei 12.846/13 tem nítida natureza penal. O referido autor sustenta, inclusive, que a responsabilização prevista na lei deve seguir as regras e os princípios do devido processo penal. 
a Constituição da República não encerra a ordem jurídica, pelo que não havendo ali regra proibitiva, possível a previsão infralegal.

A previsão de responsabilidade objetiva das pessoas jurídicas não chega nem mesmo a ser uma inovação da Lei Anticorrupção: a responsabilização objetiva de pessoas jurídicas já foi adotada na legislação ambiental (art. 14, §1º da Lei nº 6.938/81) (BRASIL, 1981), pelo Código de Defesa do Consumidor (arts. 12 a 14) (BRASIL, 1990) e até no próprio Código Civil (Arts. 931, 932, III, e 933) (MOREIRA NETO; FREITAS, 2014, p. 14; ZOCKUN, 2017, p. 18). Inclusive, a própria CRFB/88 (BRASIL, 1988) estabelece expressamente a hipótese de responsabilização objetiva das pessoas jurídicas de direito público e das de direito privado prestadoras de serviço público (art. 37, §6 , da CRFB) (ZOCKUN, 2017).

Ademais, essa mesma arguição se funda erroneamente em diversos princípios do Direito Penal (como o próprio princípio da culpabilidade) para embasar a alegação de inconstitucionalidade. Ora, se não há responsabilidade penal na referida lei, também não se aplicam os princípios próprios dessa seara, como demonstrado no parecer da Procuradoria-Geral da República. ${ }^{10}$

Pode-se questionar a existência de eventual inconstitucionalidade formal orgânica no que toca à atribuição de abrangência nacional à responsabilização administrativa no âmbito da Lei Anticorrupção, ${ }^{11}$ como levanta Di Pietro (2016, p. 1004).

Não haveria discussão acerca da abrangência nacional da responsabilização civil, uma vez que é competência privativa da União legislar sobre direito civil (art. 22, I, CRFB). No entanto, quanto à responsabilidade administrativa, argumenta-se que a União não poderia legislar no âmbito dos Estados, Municípios e DF, sob pena de violação ao pacto federativo. A despeito da louvável intenção legislativa de uniformização da matéria, a disciplina pela União da responsabilidade administrativa é questionável.

A alegação de que o fundamento constitucional das infrações administrativas previstas na Lei Anticorrupção seria o mesmo dos atos de improbidade administrativa (art. 37, \$4 CRFB) não parece muito sólida, sendo necessário um relevante esforço hermenêutico para incluir a Lei Anticorrupção nesse dispositivo.

Não obstante, é fato que certos autores já vêm aderindo a essa ideia (OLIVEIRA, 2015 apud DI PIETRO, 2016, p. 1004; FERRAZ, 2014, p. 35), alguns chegando a defender que a Lei Anticorrupção seria, na verdade, uma "Lei de Improbidade Empresarial." (FERRAZ, 2014). Como aponta Di Pietro (2016, p. 1004), esse assunto ainda é tormentoso, não sendo o objeto central deste artigo.

Independentemente do caráter nacional ou federal da responsabilização administrativa prevista na Lei Anticorrupção, é certo que a referida lei estabeleceu dois tipos de responsabilização: civil e administrativa. Resta, agora, definir a amplitude subjetiva das

10 Cf. Parecer n 395/2016-AsJConst/SAJ/PGR, 2016 (BRASIL, 2016a).

11 "Art. $1^{\circ}$. Esta Lei dispõe sobre a responsabilização objetiva administrativa e civil de pessoas jurídicas pela prática de atos contra a administração pública, nacional ou estrangeira." (BRASIL, 2013, on-line, grifo nosso). 
espécies de responsabilização previstas neste diploma normativo. A grande questão que se coloca aqui é se a Lei Anticorrupção se restringe à responsabilização das pessoas jurídicas pela prática dos atos lesivos que define ou se essa responsabilização também abrange as pessoas físicas que concorrem para a prática destes atos.

Em outras palavras, investiga-se se a responsabilização das pessoas físicas também é tratada na Lei $n^{\circ}$ 12.846/13 ou se segue a disciplina dos demais diplomas que compõem esse "sistema normativo de defesa da moralidade" (MOREIRA NETO; FREITAS, 2014, p. 10), tal como a Lei de Improbidade Administrativa. Por conta do curto tempo de vigência da Lei Anticorrupção, essa questão ainda não foi tratada com tamanha profundida pela doutrina que disserta sobre o tema. Não obstante, já são encontradas algumas opiniões sobre o que se levanta.

Di Pietro parece entender que a Lei $\mathrm{n}^{\mathrm{o}}$ 12.846/13 abrange tanto a responsabilidade das pessoas jurídicas quanto das pessoas físicas que concorrem para a prática do ato ilícito. No primeiro caso, a responsabilidade seria objetiva, enquanto a responsabilidade das pessoas físicas continuaria sendo subjetiva, seguindo a regra geral do ordenamento jurídico brasileiro. A autora afirma essa opinião tanto nas edições mais recentes do seu Manual (DI PIETRO, 2016, p. 1004) quanto na recente obra "Lei Anticorrupção Comentada" (DI PIETRO; MARRARA, 2017, p. 115 e ss.), na qual disserta sobre o art. $6^{\circ}$ da Lei Anticorrupção.

Di Pietro sustenta sua posição na interpretação conjunta dos artigos $3^{012}$ e $14^{13}$ da Lei $n^{\circ}$ 12.846/2013 (BRASIL, 2013). No primeiro artigo, o legislador aponta que a responsabilidade da pessoa jurídica não exclui a responsabilidade da pessoa física que concorrer para a prática do ato ilícito, enquanto, no art. 14, é prevista a possibilidade de desconsideração da personalidade jurídica para que os efeitos das sanções previstas na lei também alcancem os administradores e sócios com poderes de administração. Conforme Di Pietro e Marrara (2017, p. 116):

A lei pune também pessoas físicas, uma vez que o art. $3^{\circ}$ da lei determina que "a responsabilização da pessoa jurídica não exclui a responsabilidade individual de seus dirigentes ou administradores ou de qualquer pessoa natural autora, coautora ou partícipe do ato ilícito". Ao contrário da pessoa jurídica, que responde objetivamente, independentemente de culpa (art. $2^{\circ}$ ), as pessoas físicas mencionadas no art. $3^{\circ}$ respondem subjetivamente, ou seja, "na medida de sua culpabilidade”, conforme o $§ 2^{\circ}$ do mesmo dispositivo. Além disso, o art. 14 da lei, inserido no capítulo pertinente ao "processo administrativo de responsabilização", prevê a desconsideração da personalidade jurídica [...].

12 "Art. $3^{\circ}$. A responsabilização da pessoa jurídica não exclui a responsabilidade individual de seus dirigentes ou administradores ou de qualquer pessoa natural, autora, coautora ou partícipe do ato ilícito. $\S 1^{\circ}$ A pessoa jurídica será responsabilizada independentemente da responsabilização individual das pessoas naturais referidas no caput. $\S 2^{\circ}$ Os dirigentes ou administradores somente serão responsabilizados por atos ilícitos na medida da sua culpabilidade." (BRASIL, 2013, on-line).

13 "Art. 14. A personalidade jurídica poderá ser desconsiderada sempre que utilizada com abuso do direito para facilitar, encobrir ou dissimular a prática dos atos ilícitos previstos nesta Lei ou para provocar confusão patrimonial, sendo estendidos todos os efeitos das sanções aplicadas à pessoa jurídica aos seus administradores e sócios com poderes de administração, observados o contraditório e a ampla defesa." (BRASIL, 2013, on-line). 
O autor Oliveira (2017, p. 47 e ss.) apresenta opinião diversa. Esse autor promove detida avaliação do art. $3^{\circ}$ da Lei $n^{\circ} 12.846$, analisando a extensão da responsabilidade individual prevista neste diploma normativo. Para Oliveira (2017, p. 47), a "Lei Anticorrupção tem a plena carga sancionatória voltada para as pessoas jurídicas, brasileiras ou estrangeiras, colhidas no âmbito de pessoas da lei disciplinada no art. $1^{\circ}$."

O art. $3^{\circ}$ da Lei Anticorrupção (BRASIL, 2013) aborda a responsabilidade "individual", podendo abranger todos os sistemas de responsabilização existentes e aplicáveis ao caso. $\mathrm{O}$ cuidado de prever esta denominação genérica ("individual”) reforça o intuito do legislador de reforçar que a punibilidade das pessoas físicas continua plenamente preservada. Nesse sentido, essa responsabilidade individual abrange todas as esferas de responsabilização (civil, administrativa e penal) e todos os diplomas que lhe disciplinam (Código Civil, Código Penal, Lei $n^{\circ} 8.492 / 92$, Lei no 8.666/93, dentre outros).

O propósito da Lei Anticorrupção foi o de realçar que as pessoas naturais continuam sujeitas a todo sistema de responsabilização existente no ordenamento jurídico brasileiro. Como este mesmo autor aponta:

$\mathrm{O}$ art. $3^{\circ}$ foi concebido para garantir a segurança jurídica na forma como o ordenamento jurídico deveria tratar a responsabilização das pessoas naturais, uma vez construído o sistema de responsabilização exclusiva das PJs pela Lei $\mathbf{n}^{\circ}$ 12.846. A temática do artigo revela o intento de assegurar a plena efetividade de todos os sistemas sancionatórios consagrados no direito posto, que estão a incidir sobre os fatos ilícitos e que projetam consequências patrimoniais e/ou punitivas, a nível pessoal, concomitantemente ao processamento e julgamento da responsabilidade apurada e atinente à PJ. A responsabilidade da pessoa jurídica não exclui a responsabilidade individual. Não poderá ser arguida como impeditivo de sanções contra pessoas naturais em face do Poder Público, no âmbito judicial (civil ou criminal) ou administrativo (em duas diversas segmentações punitivas). (OLIVEIRA, 2017, p. 47, grifo nosso).

Augusto Neves Dal Pozzo e os demais autores da obra conjunta que comenta a Lei Anticorrupção (DAL POZZO et al., 2014) parecem aderir a essa ideia, apontando que a responsabilização das pessoas físicas prevista no art. $3^{\circ}$ não segue o procedimento da Lei $n^{\circ}$ 12.846/13 nem se submete às suas sanções. Nessa mesma linha, os artigos que disciplinam as sanções (art. $6^{\circ}$ e 19) dispõem expressamente que elas se aplicam às pessoas jurídicas, não citando as pessoas físicas. Para o autor, como se trata do estabelecimento de sanções, esses dispositivos não podem ser interpretados de forma extensiva, o que limita a aplicação das sanções específicas da Lei Anticorrupção às pessoas jurídicas.

Carvalhosa (2014a, p. 68) também afirma que os dirigentes e funcionários da pessoa jurídica autora do ato corrupto não são sujeitos ativos dos delitos tipificados nesta Lei. Para o autor, "o sujeito ativo é sempre e unicamente a pessoa jurídica". Carvalhosa (2014a, p. 69) ainda afirma que, no caso de concorrência da pessoa física na prática dos atos ilícitos previstos na Lei ${ }^{\circ}$ 12.846/2013, ela deve ser responsabilizada em instâncias e procedimentos diversos dos previstos na Lei Anticorrupção. 
Concordamos com o posicionamento desses últimos autores, no sentido de que a responsabilização civil e administrativa prevista na Lei $\mathrm{n}^{\mathrm{O}} 12.846 / 13$ se restringe às pessoas jurídicas. Isto se depreende principalmente de uma interpretação sistemática do art. $1^{\mathrm{O}} \mathrm{em}$ combinação com os art. $5^{\circ}$ (que fixa os atos lesivos) e com os artigos $6^{\circ}$ e 19 (que fixam as sanções) desta lei.

artigo inaugural fixa o objeto e o âmbito de aplicação da Lei Anticorrupção, tal como determinado pelo art. $7^{\circ}$ da Lei complementar no 95/1998 (Lei de técnica legislativa) (BRASIL, 1998). Em sentido contínuo, esse mesmo dispositivo restringe expressamente a responsabilização civil e administrativa prevista na Lei Anticorrupção às pessoas jurídicas. Ademais, ao definir os atos lesivos no art. $5^{\circ}$, o legislador remete diretamente às pessoas jurídicas dispostas no parágrafo único do art. $1^{\circ}$, o que dá a entender que os sujeitos ativos destes atos só podem ser pessoas jurídicas.

Por fim, os artigos $6^{\circ}$ e 19 apenas citam a responsabilização da pessoa jurídica ao dispor sobre a aplicação das sanções administrativas e civis previstas nesta lei. Desses dispositivos se depreende que apenas as pessoas jurídicas se sujeitam aos procedimentos de responsabilização administrativa e judicial especificamente previstos na Lei $n^{\circ} 12.846 / 13$ : a responsabilização individual das pessoas físicas que concorrem na prática dos atos ilícitos previstos na Lei Anticorrupção mantém-se regulada pelos demais diplomas normativos que compõem o sistema de responsabilização.

Quanto à possibilidade de desconsideração da personalidade jurídica prevista no art. 14 da Lei Anticorrupção, entendemos que essa previsão não é suficiente para mudar a amplitude subjetiva deste diploma. Trata-se de uma hipótese excepcional, aplicável quando a personalidade jurídica for "[...] utilizada com abuso do direito para facilitar, encobrir ou dissimular a prática dos atos ilícitos previstos nesta Lei ou para provocar confusão patrimonial [...]." (BRASIL, 2013, on-line). ${ }^{14}$

Da intelecção deste dispositivo, depreende-se que a Lei Anticorrupção adota a teoria maior da disregard doctrine, ${ }^{15}$ exigindo a presença de dois requisitos legais para deferimento da desconsideração: I - Existência de ato ilícito tipificado no art. $5^{\circ}$ da Lei 12.846/2013; II - Abuso da personalidade jurídica, consubstanciado no desvio de finalidade da personalidade jurídica para a prática dos atos ilícitos definidos na Lei Anticorrupção ou mesmo pela confusão patrimonial. Este último é o requisito que especifica a teoria maior (FARIAS; ROSENVALD, 2016, p. 472): a simples e isolada concorrência do ato lesivo não é suficiente para ensejar a desconsideração.

Na verdade, havendo desconsideração, as sanções continuam sendo aplicadas contra a pessoa jurídica (responsabilidade primária), havendo uma mera extensão dos seus efeitos para

14 "Art. 14. A personalidade jurídica poderá ser desconsiderada sempre que utilizada com abuso do direito para facilitar, encobrir ou dissimular a prática dos atos ilícitos previstos nesta Lei ou para provocar confusão patrimonial, sendo estendidos todos os efeitos das sanções aplicadas à pessoa jurídica aos seus administradores e sócios com poderes de administração, observados o contraditório e a ampla defesa." (BRASIL, 2013, on-line). 
também atingir o patrimônio dos administradores e sócios com poderes de administração, desde que atendidos os requisitos legais. A responsabilidade administrativa ou civil determinada na Lei continua sendo da pessoa jurídica, mesmo que possa reverberar no patrimônio das pessoas físicas que compõem o seu quadro societário.

A Lei Anticorrupção não determina quais sanções poderiam ser estendidas aos administradores e sócios com poderes de administração, o que pode gerar certos inconvenientes práticos. Analisando as sanções administrativas e judiciais, observa-se que a grande maioria das sanções simplesmente não podem ser estendidas a essas pessoas físicas: como estender, por exemplo, a sanção administrativa de publicação extraordinária da decisão condenatória?

Entende-se, portanto, que só as sanções pecuniárias "diretas"16 podem ser estendidas via aplicação da desconsideração da personalidade jurídica, por clara impossibilidade material de extensão das demais. $O$ procedimento que esta desconsideração deve seguir não está previsto na Lei Anticorrupção, pelo que se aplica o disposto no Código de Processo Civil para instauração do incidente de desconsideração da personalidade jurídica (arts. 133 a 137 do CPC/2015) (BRASIL, 2015b).

\section{SUJEITOS ATIVOS E PASSIVOS}

Uma vez definida a amplitude subjetiva da responsabilização civil e administrativa prevista na Lei Anticorrupção, ou seja, que esta responsabilização se restringe às pessoas jurídicas, resta analisar quais pessoas jurídicas podem ser sujeitos ativos dos atos lesivos nela definidos.

O caput do art. $1^{\mathrm{o}}$ da Lei Anticorrupção ${ }^{17}$ não indica a quais pessoas jurídicas a lei se destina. $O$ parágrafo único do mesmo artigo sugere que a intenção do legislador foi abranger o maior número de pessoas jurídicas de direito privado possível. Nesse sentido, apontam Fortini e Vieira (2015, p. 164):

Vê-se que a Lei ${ }^{\circ} 12.846 / 13$ pretendeu alcançar o mais amplo espectro de pessoas jurídicas de direito privado, sejam nacionais ou estrangeiras, abrangendo as sociedades de fato e as sociedades não personificadas, que, de qualquer modo ou sob qualquer título, mantenham relação com a Administração Pública.

Todavia, há discussão na doutrina a respeito da possível responsabilização de outras entidades não arroladas expressamente no parágrafo único. Citam-se, por exemplo, as entidades religiosas e os partidos políticos.

16 Multa (art. $6^{\circ}$, I, da Lei n ${ }^{\circ}$ 12.846/13) e/ou "Perdimento dos bens, direitos ou valores que representem vantagem ou proveito direta ou indiretamente obtidos da infração." (art. 19º, I, da Lei n $\left.{ }^{\circ} 12.846 / 13\right)$. (BRASIL, 2013, on-line).

17 "Art. $1^{\circ}$. [...] Parágrafo único. Aplica-se o disposto nesta Lei às sociedades empresárias e às sociedades simples, personificadas ou não, independentemente da forma de organização ou modelo societário adotado, bem como a quaisquer fundações, associações de entidades ou pessoas, ou sociedades estrangeiras, que tenham sede, filial ou representação no território brasileiro, constituídas de fato ou de direito, ainda que temporariamente." (BRASIL, 2013, on-line). 
A despeito da dúvida que a redação do parágrafo único proporciona, parece-nos que o intuito é abranger o maior número possível de pessoas jurídicas, não fazendo sentido excluir ou restringir do seu âmbito de aplicação certa pessoa jurídica de direito privado que pratique atos de corrupção definidos por este diploma.

O autor Leal (2014, p. 29) recorda que os partidos políticos e as entidades religiosas são espécies de associações, de forma que estariam plenamente abrangidos pelo texto do dispositivo legal. $\mathrm{O}$ autor defende que clube recreativos e clubes de futebol podem praticar atos de corrupção definidos por esta lei (classificando-os como espécies de associações), o que reforça o caráter amplíssimo da sujeição ativa na Lei Anticorrupção.

Em sentido análogo, Santos, Bertoncini e Custódio Filho (2015, p. 80) afirmam que os partidos políticos e as entidades religiosas não estão imunes aos dispositivos da Lei Anticorrupção: $\mathrm{o}$ art. $1^{\circ}$ desta lei fala em "quaisquer fundações, associações de entidades ou pessoas, ou sociedades estrangeiras", abrangendo estas pessoas jurídicas.

Carvalhosa (2014a, p. 70) caminha no mesmo sentido, compreendendo que a regra prescreve amplo polo ativo para os atos de corrupção, incluindo os partidos políticos e qualquer tipo de associação em sua abrangência.

Todavia, há discussão na doutrina diante da redação do parágrafo único do referido artigo que, para alguns, estaria enumerando as entidades alcançáveis pela lei, principalmente quanto às entidades religiosas e os partidos políticos.

Nesse sentido, interpretando literalmente o art. $1^{\circ}$ da Lei 12.846/13, Petrelluzzi e Rizek Júnior $(2014$, p. 55) sustentam que as entidades religiosas e os partidos políticos não se incluem no rol de legitimados ativos para a prática dos atos lesivos à Administração Pública. Na lição destes autores: "os partidos políticos e suas fundações podem ser sujeitos passivos dos atos lesivos à administração pública por receberem recursos do Poder Público, mas não estão inclusos na relação de possíveis sujeitos ativos da Lei Anticorrupção." (PETRELLUZZI; RIZEK JÚNIOR, 2014, p. 55).

Seguindo a mesma linha, Zymler e Dios (2016, p. 40) afirmam que os partidos jurídicos e as entidades religiosas foram expressamente excluídos da abrangência da Lei Anticorrupção. Ademais, na visão dos autores, o caráter sancionador da norma afastaria "a possibilidade de aplicação analógica ou interpretação extensiva no sentido de abranger essas entidades." (ZYMLER; DIOS, 2016, p. 40).

Para Fernandes e Costa (2014, p. 38), mesmo que tal omissão legislativa tenha sido um grande equívoco do legislador ordinário, não é possível que se amplie o sentido do referido dispositivo, pois, sem expressa disposição legal, o aplicador não poderia utilizar-se da analogia para aplicar penalidades ou mesmo restringir direitos.

Pode-se aduzir que o fato de o art. 44 do Código Civil (BRASIL, 2002) dispor os partidos políticos e as organizações religiosas como espécies autônomas de pessoas jurídicas não elimina o caráter associativo dessas pessoas jurídicas. Na verdade, conforme lembra Cretella Júnior (1965, p. 7-14) a ideia da divisão de pessoas jurídicas a partir do seu substrato ("cor- 
porativo/associativo" ou "fundacional/institucional") trata-se de objeto da Teoria Geral do Direito, não se restringindo ao Direito Civil.

Essa divisão foi inicialmente estabelecida pelo Direito Romano, dividindo as pessoas jurídicas em dois principais grupos: as que se constituíam em uma coletividade personalizada (universitas personarum) e as que se constituíam em um patrimônio personalizado (universitas bonorum, sendo que bonorum significa "coisa"). No caso da universalidade de bens, o que the dá unidade é sua instrução a um fim determinado.

Dito isso, não há qualquer dúvida de que os partidos políticos e as organizações religiosas se apresentam como uma coletividade personalizada (universitas personarum), tendo nítido caráter associativo.

A amplitude da responsabilização prevista na Lei Anticorrupção é um dos seus traços mais característicos, atingindo até pessoas jurídicas estrangeiras (polo ativo) ou atos contra a Administração Pública de outro país (polo passivo). Excluir do seu âmbito de incidência pessoas jurídicas de direito privado nacionais que pratiquem atos lesivos em sua relação com a Administração Pública seria um contrassenso, rompendo a interpretação sistemática da Lei Anticorrupção .

No caso dos partidos políticos, essa questão fica ainda mais latente. É cristalina a possibilidade de seu envolvimento em atos de corrupção, principalmente por conta da estreita relação que guardam com o aparato estatal, ainda mais no atual contexto político nacional. Pelo exposto, discordamos do posicionamento que defende a não incidência da Lei Anticorrupção nos atos praticados por essas pessoas jurídicas, especialmente no caso dos partidos políticos. ${ }^{18}$

Seguindo a mesma linha argumentativa, também não há qualquer óbice para que as entidades de colaboração com o Poder Público (tais como Organizações sociais, Organizações da Sociedade Civil, Organizações da Sociedade Civil de Interesse Público, etc.) (CARVALHOSA, 2014a, p. 60) integrem o polo ativo desses atos lesivos, estando plenamente sujeitas à responsabilização civil e administrativa pela incidência da Lei Anticorrupção.

Uma questão que surge da análise deste dispositivo legal é a possibilidade de entes da Administração Indireta serem responsabilizados com base na Lei Anticorrupção. Da redação do parágrafo único, fica claro que pessoas jurídicas de direito público estão excluídas.

Mas, ainda seria possível cogitar se as empresas públicas e sociedades de economia mista podem ser responsabilizadas civil e administrativamente no ambiente da Lei Anticorrupção. Poder-se-ia indagar se esta responsabilização não levaria a um paradoxo: o Estado sendo responsabilizado por atos de corrupção contra o próprio Estado. Nas palavras de Hage Sobrinho (2014, p. 43): "causa espécie imaginar a aplicação, pelo Estado, de todas as sanções previstas na Lei (ou ao menos de algumas delas) a empresas por ele próprio criadas e, em alguns casos, mantidas com a receita tributária, para a realização de fins de interesse público."

O parágrafo único do art. $1^{\circ}$ menciona "quaisquer fundações", "sociedades empresárias" e "sociedades independentemente da forma de organização ou modelo societário adotado",

18 Ver: (PETRELLUZZI; RIZEK JUNIOR, 2014). 
de forma que as entidades supracitadas não escapariam dos tentáculos do diploma legal. Carvalhosa (2014a, p. 60), indo nesta direção, admite expressamente a incidência da Lei Anticorrupção às fundações públicas de direito privado.

Ademais, violaria a ideia de isonomia pensar que esses entes "públicos" estariam imunes à incidência da Lei Anticorrupção apenas por estarem vinculados à Administração Direta, principalmente no caso das empresas estatais que atuam em concorrência com a iniciativa privada. Pela própria redação do parágrafo único do art. $1^{\circ}$ fica claro que o legislador (felizmente) não teve a intenção de excluir essas entidades do âmbito de incidência da Lei $n^{\circ}$ 12.846/13 (BRASIL, 2013).

Lembra-se, inclusive, que pode haver dispensa de licitação nas contratações feitas por sociedade de economia mista e empresas públicas (art. 24, XXIII, da Lei 8.666/93) (BRASIL, 1993), o que potencializa o risco de atos lesivos contra a Administração Pública praticados pelas próprias empresas estatais, mesmo que se possa supor risco potencialmente menor se comparado com as empresas da iniciativa privada. ${ }^{19}$

A Lei 13.303/2016 (BRASIL, 2016b) ${ }^{20}$ parece ter solucionado essa controvérsia, dispondo sobre a Lei Anticorrupção em algum dos seus artigos. No art. 17, §4 $4^{\circ}$, estabeleceu-se a exigência legal para que os administradores dessas pessoas jurídicas participem (na posse e anualmente) de programas de treinamentos que envolvam a Lei Anticorrupção. Já o art. 94 da mesma lei dispõe expressamente sobre a aplicação das sanções da Lei Anticorrupção às empresas públicas e sociedade de economia mista, salvo as previstas no art. 19, II, III e IV, da Lei 12.846/13 (BRASIL, 2013). Assim, expurgou-se qualquer dúvida acerca da aplicação desta lei às empresas estatais.

Ademais, registra-se a possibilidade de uma aparente confusão entre o polo ativo e passivo do ato de corrupção. Isso pode ocorrer quando, por exemplo, uma empresa pública, com patrimônio inteiramente pertencente à União, praticar um ato de corrupção contra a própria União.

Não se trata da hipótese de confusão obrigacional, quando, na mesma pessoa, confundem-se as qualidades de credor e devedor (TARTUCE, 2014, p. 405). Na ocorrência de um ato lesivo tipificado pela Lei Anticorrupção, ainda que a "vítima" seja certa pessoa jurídica da Administração Direta ou Indireta, sempre haverá lesão ao interesse público e aos princípios da Administração Pública (mesmo que de forma indireta). O instituto da confusão não se aplica a esta situação, pois não há apenas interesses particulares em jogo, como no estabelecimento de uma relação obrigacional entre credor e devedor.

Na verdade, como apontam os autores Moreira Neto e Freitas (2014, p. 12-13), o principal fundamento constitucional desta Lei Anticorrupção é o princípio da moralidade administrativa, inserto no art. 37 da CRFB. Ainda que a União, no caso concreto, não

19 Sobre o amplo risco de corrupção nos procedimentos licitatórios, ver: Fortini e Motta (2016).

20 Esta lei estabeleceu o "estatuto jurídico da empresa pública, da sociedade de economia mista e de suas subsidiárias, no âmbito da União, dos Estados, do Distrito Federal e dos Municípios." (BRASIL, 2016b, on-line). 
tenha o interesse em prosseguir com a ação de responsabilização por envolver interesses de suas entidades, ainda resta o interesse público de proteção à moralidade administrativa e ao erário público.

Por esses motivos, o próprio Ministério Público é legitimado para ajuizar a ação de responsabilização judicial por atos de corrupção (legitimação concorrente, art. 19 da Lei n ${ }^{0}$ 12.846/13), podendo inclusive pleitear a aplicação das sanções administrativas por conta de eventual omissão do ente federativo competente para promover a responsabilização administrativa (art. 20 da Lei $n^{\circ}$ 12.846/13) (BRASIL, 2013).

Assim, conforme se afirmou acima, essa confusão entre polo ativo e passivo do ato de corrupção é apenas aparente. Porém, concordando em parte com Hage Sobrinho (2014, p. 43), registra-se que não há uma aplicabilidade imediata e integral de todas as sanções previstas no art. 19 da Lei n ${ }^{0}$ 12.846/13. Não é possível aplicar a sanção de dissolução compulsória aos entes estatais submetidos à Lei Anticorrupção.

Como bem lembrado pelo autor, a criação dessas entidades de direito privado da Administração Indireta depende de, no mínimo, lei específica autorizando sua criação (art. 37, XIX, CRFB), de forma que sua dissolução deve seguir simetricamente a mesma disciplina. Assim, não seria juridicamente viável dissolver/interditar/suspender os referidos entes públicos via sentença judicial, até porque a exigência de lei específica decorre de expressa previsão constitucional.

A Lei 13.303/2016 seguiu nessa direção. O legislador ordinário, atento a esta incompatibilidade, estabeleceu expressamente, no art. 94 da Lei 13.303/2016, a não aplicabilidade dessas sanções às empresas públicas e às sociedades de economia mista, incluindo também a vedação à sanção prevista no art. 19, IV da Lei 12.846/2013 de "proibição de receber incentivos, subsídios, subvenções, doações ou empréstimos de órgãos ou entidades públicas e de instituições financeiras públicas ou controladas pelo poder público, pelo prazo mínimo de 1 (um) e máximo de 5 (cinco) anos." (BRASIL, 2013, on-line).

No entanto, ficam plenamente aplicáveis as penas de multa (art. $6^{\circ}$, I, da Lei $\mathrm{n}^{\mathrm{o}}$ 12.846/13) e perdimento de bens, direitos ou valores (art. 19, I, da Lei $n^{0} 12.846 / 13$ ) no caso em questão, uma vez que o art. 94 da Lei 13.303/2016 não excepcionou as sanções pecuniárias. Ademais, o art. 24 da Lei 12.846/2013 estabelece que estes valores serão destinados preferencialmente às entidades e aos órgãos lesados.

Assim, nada impede que essas penas pecuniárias sejam aplicadas e que o valor seja destinado para outras entidades de outros níveis federativos, atendendo sempre ao interesse público. Dessa forma, exclui-se o aparente paradoxo de aplicação de multas por determinado Ente Federativo a uma empresa por ele criada (HAGE SOBRINHO, 2014, p. 43).

Feita a análise dos possíveis sujeitos ativos dos atos lesivos definidos na Lei n ${ }^{\circ}$ 12.846/13, torna-se possível entender porque se deve referir à Lei como "Lei Anticorrupção".

Por isso, entendemos que é mais técnico suprimir a característica "empresarial" do seu nome popular, sendo apenas "Lei Anticorrupção". Ademais, tal análise da amplitude subjetiva 
dessa lei também ajuda a entender porque a "Lei Anticorrupção" não é um espelho perfeito da Lei de Improbidade Administrativa, como defende o autor Ferraz (2014), que inclusive a chama de "Lei de Improbidade Empresarial".

A Lei Anticorrupção pode atingir condutas não empresariais (ex: fundações) e até de agentes públicos (agentes de pessoas jurídicas de direito privado da Administração Indireta), não se excluindo com a Lei de Improbidade Administrativa. É verdade que ambas as leis se complementam, no sentido de que a Lei Anticorrupção mira a responsabilização das pessoas jurídicas e a Lei de Improbidade foca nas pessoas físicas.

Por fim, investigam-se os possíveis sujeitos passivos da Lei Anticorrupção. Aqui não há grandes discussões: o art. $5^{\circ}$, caput, da Lei ${ }^{\circ}$ 12.846/13 (BRASIL, 2013, on-line) ${ }^{21}$ disciplina que os atos lesivos serão aqueles praticados contra a "administração pública, nacional ou estrangeira".

A expressão Administração Pública, quando analisada do ponto de vista subjetivo ou formal, envolve tanto a Administração Pública Direta (entes federados e seus órgãos) quanto a Administração Pública Indireta (autarquias, fundações, consórcios, empresas públicas e sociedades de economia mista) (CARVALHO FILHO, 2014, p. 457; JUSTEN FILHO, 2012, p. 266; MEIRELLES, 2010, p. 65-66). Quanto à Administração Pública estrangeira, adota-se o paralelismo de formas, de acordo com a especificidade da organização administrativa de cada país.

Da redação do aludido art. $5^{\circ}$ da Lei Anticorrupção extrai-se o caráter extraterritorial (também chamado de transnacional ${ }^{22}$ ou ultraterritorial ${ }^{23}$ ) da Lei Anticorrupção, podendo atingir atos praticados no exterior contra pessoas jurídicas estrangeiras. Trata-se de uma clara aplicação do princípio da extraterritorialidade, com nítida inspiração no FCPA e no UK bribery act. Porém, é válido lembrar que não se trata de responsabilidade penal, tal como estabelecida por estes dois diplomas. Apesar do princípio da extraterritorialidade geralmente ser relacionado com o Direito Penal, não se trata de um conceito exclusivo desse campo.

A extraterritorialidade significa uma extensão de jurisdição para abarcar atos fora do limite territorial do país, não se limitando à responsabilização penal.

O fundamento da extraterritorialidade, previsto na Lei Anticorrupção, encontra-se nos dispositivos da mesma lei (arts. $1^{\circ}$ e $5^{\circ}$ da Lei n $\left.{ }^{\circ} 12.846 / 13\right)$, e não no Código Penal (BRASIL, 1940). Como já foi exaustivamente afirmado neste trabalho e é disposto expressamente no art. $1^{\circ}$ da Lei n ${ }^{\circ} 12.846 / 2013$, a Lei Anticorrupção trata apenas da responsabilização civil e administrativa das pessoas jurídicas.

21 "Art. $5^{\circ}$. Constituem atos lesivos à administração pública, nacional ou estrangeira, para os fins desta Lei, todos aqueles praticados pelas pessoas jurídicas mencionadas no parágrafo único do art. $1^{\circ}$, que atentem contra o patrimônio público nacional ou estrangeiro, contra princípios da administração pública ou contra os compromissos internacionais assumidos pelo Brasil, assim definidos: [...].” (BRASIL, 2013, on-line, grifo nosso).

22 Ver: Moreira Neto e Freitas (2014, p. 10).

23 Ver: Carvalhosa (2014a, p. 131). 


\section{FCPA, UK BRIBERY ACT E LEI ANTICORRUPÇÃO: ANÁLISE COMPA- RATIVA DA AMPLITUDE SUBJETIVA DESSES DIPLOMAS}

Por fim, cabe apresentar breve panorama da amplitude subjetiva dos dois diplomas paradigmas da normativização do combate à corrupção no cenário internacional: o Foreign Corrupt Practices Act (FCPA) e o "United Kingdom bribery act".

O FCPA surgiu no ano de 1977 nos Estados Unidos, após uma série de escândalos sobre pagamentos de propinas tanto no ambiente doméstico quanto no internacional (FORTINI; VIEIRA, 2015). Um dos principais traços distintivos do FCPA em comparação ao UK bribery act e à própria Lei Anticorrupção brasileira é o direcionamento subjetivo daquele diploma.

O sistema anticorrupção americano possui um amplo espectro normativo, tratando de forma apartada os atos de corrupção internos e externos. Como aponta Fortini e Vieira (2015), o FCPA mira apenas a oferta e efetiva realização de pagamentos indevidos aos "foreign officials". ${ }^{24}$ Se o ato de corrupção for praticado em conluio com agente público americano, incide a legislação esparsa que rege os atos de corrupção internos, variando, inclusive, conforme a legislação específica de cada Estado. No âmbito federal, a peça central do sistema interno de combate à corrupção é o 18 U.S.C.A. ${ }^{25}$

No âmbito no FCPA, Tillipman (2014, p. 4) lembra que a definição de foreing officials é ampla, abrangendo agentes públicos de governos estrangeiros (incluindo seus órgãos, departamentos, agências), agentes de organizações internacionais (como o Banco Mundial e a Organização dos Estados Americanos), além de eventuais representantes que atuem em nome de governos estrangeiros em missões oficiais.

Percebe-se que existem significativas diferenças estruturais entre os dois sistemas, inclusive quanto à definição dos elementos que guiarão a amplitude subjetiva de cada diploma normativo. O sistema de combate à corrupção americano secciona-se conforme a vinculação (interna ou externa) do agente público envolvido no ato de corrupção. Por outro lado, o sistema brasileiro divide-se a partir da natureza da pessoa envolvida no ato danoso: enquanto a Lei Anticorrupção se volta à punibilidade das pessoas jurídicas corruptas, a Lei de Improbidade Administrativa foca na responsabilização das pessoas físicas ímprobas (agentes públicos e, extensivamente, terceiros). ${ }^{26}$

Aqui, não há diferença quanto ao destinatário da propina (FORTINI; VIEIRA, 2015). $\mathrm{Na}$ verdade, os dois diplomas nacionais tipificam atos lesivos que não necessariamente envolvem a oferta ou pagamento de vantagens indevidas a agentes públicos (Art. 10 e 11 da Lei 8.429/92 e Art. $5^{\circ}$, III a V da Lei 12.846/2013).

Apesar desta distinção entre os dois sistemas, tanto a Lei Anticorrupção quanto o FCPA possuem um caráter extraterritorial, podendo incidir sobre atos de corrupção praticados por pessoas jurídicas estrangeiras, inclusive no exterior. No caso do FCPA, a jurisdição americana

24 Tradução livre: agentes públicos estrangeiros.

25 Ver: (TILLIPMAN, 2014, p. 5-10).

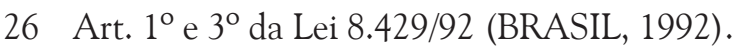

R. Opin. Jur., Fortaleza, ano 17, n. 25, p.81-106, maio/ago. 2019 
pode incidir a partir de dois critérios principais (TILLIPMAN, 2014, p. 3-4): I - Critério territorial, abrangendo ofertas ou pagamentos indevidos praticados em território americano, inclusive por agentes ou empresas estrangeiras; II - Critério da nacionalidade, aplicando-se aos atos de corrupção praticados fora do território americano, desde que envolvam interesses domésticos ${ }^{27}$ ou "emissários" americanos. ${ }^{28}$

Para responsabilização no âmbito da Lei Anticorrupção, exige-se que a sociedade estrangeira tenha filial, sede ou representação no território brasileiro, o que acaba lhe conferindo um caráter mais restritivo frente à abrangência subjetiva do FCPA.

Partindo destas características, o UK bribery act se aproxima do FCPA quanto à amplitude subjetiva, mas se afasta quanto ao direcionamento da responsabilização. O UK bribery act surgiu no Reino Unido em um contexto de forte pressão internacional, principalmente por ser signatário de diversos acordos para eliminação da corrupção. ${ }^{29}$ Foi aprovado no ano de 2010, entrando em vigor apenas em julho de 2011 (LIPPMAN, 2013, p. 652).

Enquanto o FCPA e a Lei Anticorrupção apresentam-se como apenas uma peça dos sistemas em que se inserem, Lippman (2013, p. 658) lembra que o UK bribery act tem a pretensão de ser o único diploma normativo do sistema anticorrupção britânico. Segundo Tillipman (2014, p. 17), sua amplitude abrange quaisquer atos de corrupção no Reino Unido ou mesmo em outros países, desde que tenham sido praticados por agentes ou companhias que tenham uma "relação próxima" com o Reino Unido. O conceito desta "relação próxima" é extremamente amplo, abrangendo cidadãos britânicos e dos territórios britânicos, residentes no Reino Unido, companhias incorporadas a partir da legislação de qualquer parte do Reino Unido, etc.

Percebe-se que a amplitude subjetiva do UK bribery act é similar à delineada no FCPA, abrangendo empresas estrangeiras que tenham mera conexão com a jurisdição destes países. Porém, quanto ao direcionamento subjetivo do regime de responsabilização, o UK bribery act incide tanto sobre atos de corrupção externos quanto internos, não havendo distinção quanto à natureza da vinculação do agente público envolvido no ato lesivo (LIPPMAN, 2013, p. 658). Neste aspecto, a regulamentação britânica assemelha-se à Lei Anticorrupção, tratando indistintamente a corrupção externa e interna.

\section{CONCLUSÃO}

Conclui-se, portanto, que a Lei Anticorrupção abrange apenas a responsabilização civil e administrativa das pessoas jurídicas, não regulando a responsabilidade individual

27 Companhias organizadas sob o regime jurídico de algum Estado da Federação americana ou mesmo cujo principal campo de atuação ocorra em território americano, cidadãos, nacionais, residentes, etc.

28 Companhias americanas ou estrangeiras (ou mesmo seus empregados, funcionários, agentes ou acionistas) que emitam títulos americanos ou que tenham a obrigação de apresentar relatórios à Comissão de Títulos e Câmbio dos Estados Unidos (SEC). 
das pessoas físicas que concorrem para a prática dos atos lesivos que define. Essa espécie de responsabilidade continua sendo regulada pelos diversos diplomas normativos já existentes, como a Lei de Improbidade Administrativa (Lei 8.429/92) e os estatutos funcionais.

Também procuramos definir com mais exatidão a questão dos possíveis sujeitos ativos que podem ser responsabilizados segundo a disciplina dessa Lei, além da aplicabilidade das sanções conforme a especificidade das pessoas jurídicas abrangidas por sua amplitude subjetiva, sempre atentos à compatibilidade lógica e sistemática entre a Lei Anticorrupção e os demais diplomas normativos que compõem o sistema normativo de combate à corrupção.

Destacou-se, assim, o caráter amplíssimo que o legislador buscou atribuir à extensão da punibilidade da Lei Anticorrupção, tanto em seu alcance subjetivo (sujeitos ativos) quanto em seu alcance objetivo, atingindo inclusive atos praticados no exterior ou contra a Administração Pública estrangeira. Ademais, analisou-se comparativamente a amplitude subjetiva da Lei Anticorrupção em contraposição à regulação estabelecida pelo FCPA e pelo UK bribery act, realçando os pontos de toque identificados na análise conjunta destes três diplomas.

A Lei Anticorrupção é imbuída do intuito de contribuir ao combate da indesejada tradição de corrupção que se arrasta na construção histórica e política do Brasil. Não faz sentido restringir o alcance legal para limites menores do que o próprio legislador ordinário buscou delimitar: interpretação contrária acabaria desvirtuando o próprio espírito da lei.

\section{REFERÊNCIAS}

AVRITZER, Leonardo; FILGUEIRAS, Fernando. Corrupção e sistema político no Brasil. Rio de Janeiro: Civilização Brasileira, 2011.

BARROSO, Luis Roberto. Ética e jeitinho brasileiro: por que a gente é assim? Conjur, 8 abr. 2017. Disponível em: <https://www.conjur.com.br/dl/palestra-barroso-jeitinho-brasileiro.pdf>. Acesso em: 1 maio 2018.

BING, Plínio Paulo. Corrupção: disfunções de governo. Repensar o Estado de ontem, hoje e sempre. Porto Alegre: Age, 2016.

BITENCOURT, Cezar Roberto. Tratado de Direito Penal: parte geral. 23. ed. São Paulo: Saraiva, 2017. v. 1.

BRASIL. Decreto-lei no 2.848, de 7 de dezembro de 1940. Código Penal. Presidência da República, Brasília, DF, 1940. Disponível em: <http://www.planalto.gov.br/ccivil_03/ Decreto-Lei/Del2848.htm >. Acesso em: 29 nov. 2018.

. Lei no 6.938, de 31 de agosto de 1981. Dispõe sobre a Política Nacional do Meio Ambiente, seus fins e mecanismos de formulação e aplicação, e dá outras providências. Presidência da República, Brasília, DF, 1981. Disponível em: <http://www.planalto.gov. br/ccivil_03/Leis/L6938.htm>. Acesso em: 29 nov. 2018. 
. Constituição (1988). Constituição da República Federativa do Brasil de 1988. Presidência da República, Brasília, DF, 1988. Disponível em: <http://www.planalto.gov. br/ccivil_03/constituicao/constituicao.htm>. Acesso em: 29 nov. 2018.

. Lei no 8.078 , de 11 de setembro de 1990. Dispõe sobre a proteção do consumidor e dá outras providências. Presidência da República, Brasília, DF, 1990. Disponível em: <http://www.planalto.gov.br/ccivil_03/Leis/L8078.htm>. Acesso em: 29 nov. 2018.

. Lei no 8.429 , de 2 de junho de 1992. Dispõe sobre as sanções aplicáveis aos agentes públicos nos casos de enriquecimento ilícito no exercício de mandato, cargo, emprego ou função na administração pública direta, indireta ou fundacional e dá outras providências. Presidência da República, Brasília, DF, 1992. Disponível em: <http://www.planalto. gov.br/ccivil_03/LEIS/L8429.htm>. Acesso em: 29 nov. 2018.

. Lei no 8.666, de 21 de junho de 1993. Regulamenta o art. 37, inciso XXI, da Constituição Federal, institui normas para licitações e contratos da Administração Pública e dá outras providências. Presidência da República, Brasília, DF, 1993. Disponível em: <http://www.planalto.gov.br/ccivil_03/LEIS/L8666cons.htm>. Acesso em: 29 nov. 2018.

. Lei Complementar no 95, de 26 de fevereiro de 1998. Dispõe sobre a elaboração, a redação, a alteração e a consolidação das leis, conforme determina o parágrafo único do art. 59 da Constituição Federal, e estabelece normas para a consolidação dos atos normativos que menciona. Presidência da República, Brasília, DF, 1998. Disponível em: <http://www.planalto.gov.br/ccivil_03/leis/lcp/Lcp95.htm>. Acesso em: 29 nov. 2018.

. Lei $\mathrm{n}^{\mathrm{O}}$ 10.046, de 10 de janeiro de 2002. Institui o Código Civil. Presidência da República, Brasília, DF, 2002. Disponível em: < http://www.planalto.gov.br/ccivil_03/ leis/2002/110406.htm>. Acesso em: 29 nov. 2018.

. Lei Complementar n ${ }^{0} 135$, de 4 de junho de 2010. Altera a Lei Complemen$\operatorname{tar} n^{\circ}$ 64, de 18 de maio de 1990, que estabelece, de acordo com o $§ 9$ - do art. 14 da Constituição Federal, casos de inelegibilidade, prazos de cessação e determina outras providências, para incluir hipóteses de inelegibilidade que visam a proteger a probidade administrativa e a moralidade no exercício do mandato. Presidência da República, Brasília, DF, 2010. Disponível em: <http://www.planalto.gov.br/ccivil_03/leis/lcp/lcp135. htm >. Acesso em: 29 nov. 2018.

. Lei n ${ }^{\circ} 12.529$, de 30 de novembro de 2011. Estrutura o Sistema Brasileiro de Defesa da Concorrência. Presidência da República, Brasília, DF, 2011. Disponível em: <http://www.planalto.gov.br/ccivil_03/_Ato2011-2014/2011/Lei/L12529.htm>. Acesso em: 29 nov. 2018.

. Lei $\mathrm{n}^{\mathrm{O}} 12.846$, de 1 de agosto de 2013. Dispõe sobre a responsabilização administrativa e civil de pessoas jurídicas pela prática de atos contra a administração pública, nacional ou estrangeira, e dá outras providências. Presidência da República, Brasília, DF, 
2013. Disponível em: <http:/www.planalto.gov.br/ccivil_03/_Ato2011-2014/2013/Lei/ L12846.htm>. Acesso em: 29 nov. 2018.

. Supremo Tribunal Federal. Ação Direta de Inconstitucionalidade no 5.261/DF. Tribunal Pleno. Relator: Ministro Marco Aurélio Mello. Brasília: 11 de março de 2015a. . Lei no 13.105, de 16 de março de 2015. Código de Processo Civil. Presidência da República, Brasília, DF, 2015b. Disponível em: <http://www.planalto.gov.br/ccivil_03/_ Ato2015-2018/2015/Lei/L13105.htm>. Acesso em: 29 nov. 2018.

- Ministério Público Federal. Procuradoria-Geral da República. Parecer no 395/2016-AsJConst/SAJ/PGR: Ação direta de inconstitucionalidade 5.261/DF. Relator: Ministro Marco Aurélio. Brasília, DF, 18 de janeiro de 2016a.

. Lei $\mathrm{n}^{\mathrm{o}} 13.303$, de 30 de junho de 2016. Dispõe sobre o estatuto jurídico da empresa pública, da sociedade de economia mista e de suas subsidiárias, no âmbito da União, dos Estados, do Distrito Federal e dos Municípios. Presidência da República, Brasília, DF, 2016b. Disponível em: <http://www.planalto.gov.br/ccivil_03/_Ato2015-2018/2016/Lei/ L13303.htm>. Acesso em: 29 nov. 2018.

BUENO, Eduardo. A coroa, a cruz e a espada: lei, ordem e corrupção no Brasil Colônia. Rio de Janeiro: Objetiva, 2006. v. 4.

CARVALHO, José Murilo de. Passado, presente e futuro da corrupção brasileira. In: AVRITZER, Leonardo et al. Corrupção: ensaios e críticas. 2. ed. Belo Horizonte: UFMG, 2012.

CARVALHO FILHO, José dos santos. Manual de Direito Administrativo. 27. ed. São Paulo: Atlas, 2014.

CARVALHOSA, Modesto, Considerações sobre a Lei anticorrupção das pessoas jurídicas: Lei n. 12.846 de 2013. São Paulo: Revista dos Tribunais, 2014a.

CARVAlHOSA, Modesto. A nova Lei da Empresa Limpa. O Estado de São Paulo, São Paulo, 29 jan. 2014b.

COELHO, Fábio Ulhôa. Curso de Direito Comercial: teoria geral das sociedades. 8. ed. São Paulo: Saraiva, 2005. v. 2.

COELHO, Nuno Manuel Morgadinho dos Santos; HERINGER, Helimara Moreira Lamounier. Foreign corrupt practices act: uma breve análise da lei que deu origem ao combate internacional da corrupção. Revista Jurídica, Curitiba, v. 1, n. 46, p. 164-187, 2017. CRETELlA JÚNIOR, José. Fundações de Direito Público. Revista de Direito Administrativo, Rio de Janeiro, v. 81, p. 7-15, jul. 1965.

CUÉLLAR, Leila; PINHO, Clóvis Alberto Bertolini de. Reflexões sobre a Lei Federal n ${ }^{\circ}$ 12.846/2013 (Lei Anticorrupção). Revista de Direito Público da Economia - RDPE, Belo Horizonte, v. 12, n. 46, p. 131-170, abr./jun. 2014. 
DAL POZZO, Antonio Araldo Ferraz et al. Lei Anticorrupção: apontamentos sobre a Lei no 12.8462013. Belo Horizonte: Fórum, 2014.

DI PIETRO, Maria Sylvia Zanella. Direito Administrativo. 29. ed. São Paulo: Atlas, 2016. DI PIETRO, Maria Sylvia Zanella; MARRARA, Thiago (Coord.). Lei Anticorrupção comentada. Belo Horizonte: Fórum, 2017.

FAORO, Raymundo. Os donos do poder: formação do patronato político brasileiro. 5 . ed. São Paulo: Globo, 2012.

FARIAS, Cristiano Chaves de; ROSENVALD, Nelson. Curso de Direito Civil. 16. ed. Salvador: Juspodivm, 2016. v. 1.

FERNANDES, Jorge Ulisses Jacoby; COSTA, Karina Amorim Sampaio. Breves comentários à lei da responsabilização administrativa e civil de pessoas jurídicas pela prática de atos contra a administração pública, nacional ou estrangeira. In: NASCIMENTO, Mellilo Dinis do (organizador) et al. Lei Anticorrupção Empresarial: aspectos críticos à Lei no 12.846/2013. Belo Horizonte: Fórum, 2014.

FERRAZ, Luciano. Reflexões sobre a Lei no 12.846/2013 e seus impactos nas relações público-privadas: lei de improbidade empresarial e não lei anticorrupção. Revista Brasileira de Direito Público - RBDP, Belo Horizonte, ano 12, n. 47, p. 33-43, out./dez. 2014.

FERREIRA, Aurélio Buarque de Holanda. Miniaurélio. 7. ed. Curitiba: Positivo, 2008. FIGUEIREDO, Luciano Raposo. A corrupção no Brasil Colônia. In: AVRITZER, Leonardo et al. Corrupção: ensaios e críticas. 2. ed. Belo Horizonte: UFMG, 2012.

FORTINI, Cristiana; MOTTA, Fabrício. Corrupção nas licitações e contratações públicas: sinais de alerta segundo a Transparência Internacional. A\&C - Revista de Direito Administrativo \& Constitucional, Belo Horizonte, v. 16, n. 64, p. 93-113, abr./jun. 2016. FORTINI, Cristiana. Uma rápida comparação entre a Lei 12.846/13 e norte-americano foreign corrupt practices act (FCPA). Direito do Estado, 24 nov. 2015. Disponível em: $<$ http://www.direitodoestado.com.br/colunistas/cristiana-fortini/uma-rapida-comparacao-entre-a-lei-1284613-e-norte-americano-foreign-corrupt-practices-act-fcpa > . Acesso em: $1^{\mathrm{o}} \mathrm{dez} .2017$.

FORTINI, Cristiana; VIEIRA, Ariana Shermam Morais. Lei anticorrupção empresarial: os riscos de sua regulamentação e implementação. In: REPOLÊS, Maria Fernanda Salcedo; DIAS, Maria Tereza Fonseca Dias (Coord.). O Direito Entre a Esfera Pública e a Autonomia Privada: transformações do direito público no ambiente democrático. Belo Horizonte: Fórum, 2015. p. 161-184.

FORTINI, Cristiana; VIEIRA, Ariane Shemam Morais. Corrupção: causas, perspectivas e a discussão sobre o princípio do bis in idem. Revista de Investigações Constitucionais, 
Curitiba, v. 5, n. 2, p. 91-112, maio/ago. 2018. Disponível em: < https://revistas.ufpr.br/ rinc/article/view/57614>. Acesso em: 3 set. 2018.

GARCIA, Emerson. A corrupção. Uma visão Jurídico-sociológica. Revista da Escola da Magistratura do Rio de Janeiro (EMERJ), Rio de Janeiro, v. 7, n. 26, p. 203-245, 2004. Disponível em: <http://www.emerj.tjrj.jus.br/revistaemerj_online/edicoes/revista26/revista26_203.pdf>. Acesso em: 18 ago. 2018.

HABIB, Sergio Brasil. Quinhentos anos de corrupção. Porto Alegre: Fabris, 1994.

HAGE SOBRINHO, Jorge. Lei 12.846/2013: Lei da Empresa Limpa. Revista dos Tribunais, São Paulo, v. 947, p. 37-55, set. 2014.

HOLANDA, Sérgio Buarque. Raízes do Brasil. São Paulo: Companhia das Letras, 1995.

HOUAISS, Antonio; VILLAR, Mauro de Salles. Dicionário Houaiss da língua portuguesa. Rio de Janeiro: Objetiva, 2001.

JUSTEN FILHO, Marçal. Curso de Direito Administrativo. 8. ed. Belo Horizonte: Fórum, 2012.

KOEHLER, Mike. The Foreign Corrupt Practices Act in the Ultimate Year of its Decade of Resurgence. Indiana Law Review, v. 43, p. 389-421, 2010. Disponível em: < https:// mckinneylaw.iu.edu/ilr/pdf/vol43p389.pdf>. Acesso em: 15 ago. 2018.

LEAL, Rogério Gesta. A Nova Lei Anticorrupção Empresarial no Brasil: Novo Marco Regulatório às Responsabilidades das Pessoas Jurídicas por Atos Atentatórios aos Bens Públicos. Fórum: Interesse Público, Belo Horizonte, v. 16, n. 88, p. 25-54, nov./dez. 2014. LIPPMAN, Julia. Business without bribery: analyzing the future of enforcement for the uk Bribery Act. Public Contract Law Journal, v. 42, n. 3, p. 649-668, 2013. Disponível em: <www.jstor.org/stable/24430292?seq=1\#page_scan_tab_contents>. Acesso em: 1 dez. 2017. MEIRELLES, Hely Lopes. Direito Administrativo Brasileiro. 36. ed. São Paulo: Malheiros, 2010.

MOREIRA NETO, Diogo de Figueiredo; FREITAS, Rafael Véras de. A juridicidade da Lei Anticorrupção: reflexões e interpretações prospectivas. Fórum Administrativo - FA, Belo Horizonte, ano 14, n. 156, p. 9-20, fev. 2014.

OLIVEIRA, José Roberto Pimenta. Comentários ao art. 3º. In: DI PIETRO, Maria Sylvia Zanella; MARRARA, Thiago (Coord.). Lei Anticorrupção comentada. Belo Horizonte: Fórum, 2017.

OSÓRIO, Fábio Medina. Teoria da improbidade administrativa: má gestão pública: corrupção: ineficiência. 3. ed. São Paulo: Revista dos Tribunais, 2013.

PALERMO, Dena. Gift Giving and Entertaining Without Violating the FCPA and UK Bribery Act. ACC Houston Chapter, 2012. Disponível em: <https://m.acc.com/chapters/ 
houst/upload/Gift-Giving-and-Entertaining-Without-Violating-the-FCPA-and-UK-Bribery-Act-ACC-July-2012-Meeting.pdf>. Acesso em: 13 ago. 2018.

PETRELLUZZI, Marco Vinicio; RIZEK JUNIOR, Rubens Naman. Lei Anticorrupção: origens, comentários e análise da legislação correlata. São Paulo: Saraiva, 2014.

ROSALEZ, Richard C.; LOEGERING, Weston C.; TERRITT, Harriet. The UK's Bribery Act and the FCPA Compared. In-House Litigator: The jornal of the committee on corporate counsel, Chicago, v. 25 n. 1, 2010. Disponível em: <http://www.americanbar.org/ content/dam/aba/events/criminal_justice/2015/2015shanghai_BriberyAct_FCPA_Compared.authcheckdam.pdf >. Acesso em: 15 ago. 2018.

SANTOS, José Anacleto Abduch; BERTONCINI, Mateus; COSTÓDIO FILHO, Ubirajara. Comentários à Lei 12.846/2013. 2. ed. São Paulo: Revista dos Tribunais, 2015.

SANTOS, José Maria dos. A política geral do Brasil. Belo Horizonte: Itatiaia, 1989.

SILVA, Marcos Fernandes Gonçaves da. A Economia Política da corrupção no Brasil. São Paulo: Senac, 2000.

SPORKIN, Stanley. The Worldwide Banning of Schmiergeld: A Look at the Foreign Corrupt Practices Act on its Twentieth Birthday. Northwestern Journal of International Law \& Business, v. 18, p. 269-281, 1997. Disponível em: <scholarlycommons.law.northwestern.edu/cgi/viewcontent.cgi?article $=1473 \&$ context $=$ njilb $>$. Acesso em: 13 ago. 2018 .

TARTUCE, Flávio. Manual de Direito Civil. 4. ed. São Paulo: Método, 2014. TILLIPMAN, Jéssica. Gifts, Hospitality \& the Government Contractor. Thomsom Reuters: Briefing Papers, n. 14-7, June 2014. Disponível em: <ssrn.com/abstract $=2467247>$. Acesso em: $1 \mathrm{dez} .2017$.

WEBER, Max. Economia e sociedade: fundamentos de sociologia compreensiva. Brasília: UnB, 1999. v. 2.

ZYMLER, Benjamin; DIOS, Laureano Canabarro. Lei Anticorrupção (Lei n. 12.846/2013): uma visão do controle externo. Belo Horizonte: Fórum, 2016.

ZOCKUN, Maurício. Comentário ao art. $1^{\circ}$. In: DI PIETRO, Maria Sylvia Zanella; MARRARA, Thiago (Coord.). Lei Anticorrupção comentada. Belo Horizonte: Fórum, 2017. 